\title{
THE ASSAULT ON THE ST. LOUIS MACHINE
}

\author{
BY LOUIS F. BUDENZ
}

\begin{abstract}
St. Louis is no longer "unashamed." Valiant efforts have been made to throw off machine rule with little success as yet, but with promise for the future. Mayor Kiel was almost defeated. $\quad$ :: $\quad$ ::
\end{abstract}

Mayor Henry W. Kiel of St. Louis and his strong political machine have again been under fire--in the recent municipal election. Since the attempt to recall the mayor two years ago, because of his secret franchise deal with the United Railways Co., the way of the machine has not been as smooth as before. Public distrust of the city administration continued to show itself in the spring of 1920 , in the defeat of thirteen of the eighteen items of the proposed municipal bond issue. Further warning was given the "ring" in the Republican primaries the following fall, when "Boss" John Schmoll, chairman of the city central committee and director of public welfare, lost the nomination for sheriff, to the surprise of himself and his opponents. And in the election immediately following, two of the three judges put forward by the Kiel-Schmoll group were beaten through the militant opposition of the local League of Women Voters.

PROMINENT REPUBLICANS DESERT THE MAYOR

Large doses of publicity also embarrassed the machine and weakened it. In a survey of the national political situation, just prior to the presidential primaries, a correspondent of the New York Times had directed attention to the St. Louis Republican organization as the best entrenched municipal machine in the country.
Shortly thereafter, it burst forth on the front page of every newspaper in the nation, through the revelation of money payments to Nat Goldstein and Robert Moore, two of its most active members, for support of Col. Frank O. Lowden for President. Goldstein is clerk of the circuit court and uncrowned head of the "court house ring," which, amalgamated with the Kiel-Schmoll "city hall crowd," makes up the machine. These revelations about him, it will be recalled, brought forth denunciations from leaders of both large political parties and did much to bury the presidential aspirations of the Illinois governor.

The approach of the municipal primaries this spring was the signal for "reform forces," encouraged by this apparent advantage, to get busy in an effort to defeat the mayor himself. A short time after the recall effort, he had announced his candidacy for a third term. Ex-Governor David R. Francis, Democrat, former ambassador to Russia, and closely connected with the United Railways Co., had publicly declared him the proper man for the place. It was therefore generally conceded that his ambitions would be seconded by all the members of that financial and utility combine known as the "Big Cinch," which has dominated St. Louis for years-no matter what their politics might be. An independent Republican club was organized, however, to oppose the 
mayor's candidacy, and Col. Robert Burkham, attorney for the school board and head of the local American Legion, was designated to run against him for the nomination. Four of the five newspapers of the city rallied to Colonel Burkham's support; the GlobeDemocrat, which had stood with the mayor all through the recall campaign and before, now suddenly deserting him. The only paper which remained with him has a negligible circulation compared to any one of the other papers.

One of the chief sources of opposition to the mayor was the third term issue. Another was the question of machine domination. The fact that twenty of the twenty-eight members of the Republican city committee were on the municipal pay roll, either at the court house or the city hall, lent vivid color to the contentions on this point. The array of political underlings and near relations of political chiefs among the officeholders mutely attested to the breakdown of the carefully drawn efficiency rules of the new city charter. These rules had been violated by the mayor as early as his first term, particularly in the appointment of Henry L. ("Hank") Weeke, a powerful ward leader, to a municipal job contrary to the charter provisions. The Civic League at that time took the case to the courts; but before a decision could be reached, it was discovered that Weeke was an alien enemy and therefore ineligible for public office. Upon his applying for citizenship rights, the federal court refused his request on the ground that he was of immoral character, because of the evidence introduced showing his connection with the underworld. His son-in-law took his place on the Republican city committee, however, and he continues to exercise his influence on appointments, through his strong hold on the "automatic vote."
THE STREET RAILWAY DEAL

A third issue was the United Railways deal, which had provoked the "recall." Colonel Burkham declared Mayor Kiel to be "the best friend the United Railways ever had." The League of Women Voters, in a review of the mayor's administration, scathingly denounced him for the deal. "Of all the acts of Mayor Kiel's administration," their statement read, "the United Railways deal stands out as flagrantly contrary to the interests of the city, and certainly did not conform to his pre-election pledge. By the settlement the company got what it sought and the city received nothing in return. The circumstances under which the settlement was made seem to indicate not only that the mayor was unfaithful to the trust which the people had reposed in him, but that he betrayed them deliberately and knowingly." This issue proved a rather one-sided one, as the mayor maintained a studied silence in regard to it. In a long account of his "achievements," published as a campaign document, no mention of the street railway deal was made at all, and it was not alluded to by him or his supporters at any subsequent time.

With all these batteries trained upon him, the mayor was victorious over Colonel Burkham by more than 11,000 votes. Col. James W. Byrnes, a business man not well known in politics, was successful in the Democratic primaries.

To the surprise of St. Louis, the Globe-Democrat declared that it could not support Mr. Kiel for the mayoralty, even though it was a Republican paper, and that it would lend its aid to the campaign for Byrnes. This, again, made four newspapers lined up against the mayor and one small newspaper for him. Other defections from the 
Republican ranks followed. A number of leading Republicans publicly announced their antagonism to the mayor, and many of them joined the nonpartisan committee which was formed to aid the Democratic nominee. Prominent among the former was Hon. Charles Nagel, former secretary of the interior under President Taft, who issued a statement on the eve of the election declaring that he did not consider himself bound by the results of the primary and that he would vote against Mayor Kiel. The effect of this revolt was seen in the election vote, which returned the mayor to his position in the city hall by a majority of 9,615-as compared to the 11,156 majority he had received over Burkham in the primary, and the 23,361 majority over his Democratic opponent, Connett, four years before. 'The old causes, that have been triumphant at St. Louis elections for years, again determined the final verdict, although by a much decreased margin.

\section{CAUSES OF MACHINE'S ENDURANCE}

These causes, touched upon in the National Municipal Review in a previous article, are easy to sum up: (1) The grip which the Republican machine has secured on the city hall through the provisions of the new charter, under which there is no chance for a minority to secure any single office in the city government, the aldermen being elected at large and the great mass of executive offices being appointed by the mayor. This gives the machine 7,000 city employes, voters and workers, to start off with. (2) The large German-American and Negro vote is still pretty solidly Republican, regardless of issues. The Germans, in the Civil War, saved St. Louis for the Union, and have been voting on that issue ever since. The politically stupid attacks made in the preceding Connett campaign, which charged Mayor Kiel with "un-Americanism" merely because of his Teutonic name, did not ease this situation. Byrnes was attacked from the platform during the campaign as unfit for office because of his Irish extraction. (3) The doubt in many minds that the Democratic city committee would improve the situation, but rather make it worse. Its hitherto hopelessly minority character has caused it to fall into the hands of elements which seek generally to be lesser partners of the opposing machine and dependents of the same financial-utility combine which dictates to the Republican organization. The fact that Colonel Byrnes had been sponsored by State Senator Mike Kinney, leader in the river wards, and that he was hazy on the transportation, and bridge issues, made this doubt appear a certainty to many voters.

A bright spot in the election results for the "reform forces" was the success of four of their five candidates for the board of education. This was due to a rather amusing error by the code revision committee of the 1919 state legislature. Under the law for many years in force, the school board could be elected by petition on an independent ticket. But the law also permitted nominations by parties at primaries or conventions, which prevented the success of any independent ticket. In fact, the two parties, by agreement, divided the board between them, and nominated on both tickets the candidates thus agreed upon. This bipartisan control of the board was a connecting link between the two party machines. Through a mistake, the revision committee omitted the sentence providing for the party nominations, and an effort to have it replaced failed at the 1921 session, principally 
through the vigilance of $\mathrm{E}$. M. Grossman, former attorney for the board. In this year's election, therefore, the issues were squarely joined, without any confusion arising from party labels.

St. Louis has been trying hard to wipe out the name "unashamed," which it received when Philadelphia was called "corrupt and contented." When the issue has been clean-cut, as it was two years ago in the "recall," either the election machinery has been scrapped by the anti-civic forces, or indifference has won. The vicious circle of interest still unites many of the leading citizens (as it did in Ed Butler's day), through their financial and utility connections with the elements playing to the underworld and breaking down the efficiency system. The long and persistent efforts of that little group of independent men and women centered around John H. Gundlach, former president of the city council, and the advent of the League of Women Voters, are undoubtedly changing the situation. It is in them that the present hope for St. Louis lies.

\title{
FEUDS AND POLITICS IN PENNSYLVANIA
}

\author{
BY EDWARD T. PAXTON \\ Bureau of Municipal Research, Philadelphia
}

The Pennsylvania legislature changed speakers during the last days of the session as a stage in bitter factional fights within the dominant

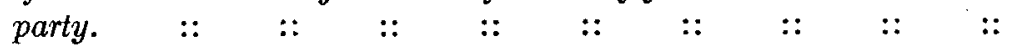

The 1921 session of the Pennsylvania legislature will be memorable for the deposing of a speaker, an unusual event, and the climax of a drama in which the principal actors are nationally of political note.

\section{THE SIDES DRAWN UP}

For years the principal "back-home" supporter of Senator Boies Penrose has been Joseph R. Grundy, president of the Pennsylvania Manufacturers' Association, whose association has furnished the principal sinews of war for the Republican state organization. The leaders of the Republican party in Pennsylvania are Governor William C. Sproul and State Senator William E. Crow, chairman of the Republican state committee. Between Senator Crow and Governor Sproul, on the one hand, and Mr. Grundy, on the other, has arisen bitter political antagonism. Prior to his illness, Senator Penrose was able to keep the factions at peace and in co-operation. With his serious illness, however, they got out of hand. The breach became irreparable at the Chicago convention, when the Grundy followers spoiled Governor Sproul's aspirations for the presidential nomination.

The 1921 legislature afforded the next test of strength between the factions. At the outset, the SproulCrow choice for speaker was upset by Penrose in favor of the former speaker, a Grundy adherent. Further than that, Penrose seems to have kept his hands off, while the Sproul-Crow forces and the Grundy forces set out to settle the leadership of the state organization. The immediate objective for Sproul 